\title{
The Murman Coast and the Northern Dvina Delta as English and Dutch Commercial Destinations in the 16th and 17th Centuries
}

\author{
J.W. VELUWENKAMP ${ }^{1}$
}

(Received 26 August 1993; accepted in revised form 30 September 1994)

\begin{abstract}
In the sixteenth and seventeenth centuries, the Murman coast trade and the Northern Dvina trade were two clearly distinct branches of Western European commerce. The Murman coast trade involved the commerce with the regional economy of the Kola Peninsula, and the Northern Dvina trade coincided with the transit trade with the Russian interior.

In the 1550s, the English established commercial relations with interior Russia via the mouth of the Northern Dvina, mainly exchanging woollen cloth and metals for north and central Russian forestry and agriculture products. In the 1570s, the Dutch followed suit, and by the second decade of the seventeenth century, they had squeezed the English almost completely out of the Russian market. The Northern Dvina trade became a major line of Dutch business, involving the transit trade with interior Russia, the exchange of the products of the north and central Russian forestry and agriculture for gold and silver money and a wide range of military stores and luxury goods. In the 1560s, the Dutch developed commercial relations with the Murman coast, exchanging locally produced exports like cod, salmon, furs and train oil for locally used imports like woollen cloth, tinware, salt, pepper, and wine. In addition, from the early 1570s, the Dutch used Kola as an alternative to the Northern Dvina mouth as a port for the transit trade with interior Russia; but they did so only until about 1585, when the tsar directed all foreign trade of interior Russia to proceed via the newly founded port of Archangel on the Northern Dvina. After that, Kola only remained an international commercial port for the local economy of the Murman coast. The Dutch continued to trade with the Murman coast on a very small scale throughout the seventeenth century, but Archangel was by far their main commercial destination in the Barents Sea area.
\end{abstract}

Key words: Northern Dvina, Archangel, Murman coast, Kola, Russian trade, Dutch trade, English trade, commercial relations

RÉSUMÉ. Au XVI e et XVII siècle, les échanges de la côte Mourmane et ceux de la Dvina septentrionale représentaient deux branches distinctes du commerce européen occidental. Les échanges de la côte Mourmane faisaient intervenir le commerce avec l'économie régionale de la presqu'île de Kola, et ceux de la Dvina septentrionale coïncidaient avec le commerce de transit avec l'intérieur de la Russie.

Dans les années 1550, les Anglais établirent des relations commerciales avec l'intérieur de la Russie via l'embouchure de la Dvina septentrionale, troquant surtout étoffes de laine et métaux contre des produits forestiers et agricoles du nord et du centre de la Russie. Durant les années 1570, les Hollandais firent de même, et, vers 1620, ils avaient presque complètement évincé les Anglais du marché russe. Les échanges de la Dvina septentrionale devinrent un important volet du monde des affaires hollandais, mettant en jeu le commerce de transit avec l'intérieur de la Russie, le troc des produits forestiers et agricoles du nord et du centre de la Russie contre de la monnaie en or et en argent, ainsi qu'une vaste gamme de fournitures militaires et d'articles de luxe. Dans les années 1560, les Hollandais établirent des relations commerciales avec la côte Mourmane, troquant des produits d'exportation locaux comme la morue, le saumon, les fourrures et l'huile de poisson contre des importations destinées à un usage local comme des étoffes de laine, de la ferblanterie, du sel, du poivre et du vin. En outre, dès le début des années 1570, les Hollandais se servirent de Kola comme alternative à l'embouchure de la Dvina en tant que port pour le commerce de transit avec l'intérieur de la Russie; mais cela ne dura que jusque vers 1585 , lorsque le tsar décida que tout le commerce extérieur de l'intérieur de la Russie devait passer par le port d'Arkhangelsk que l'on venait de créer sur la Dvina septentrionale. Après quoi, Kola ne resta un port de commerce international que pour la côte Mourmane. Les Hollandais continuèrent de commercer avec la côte Mourmane à très petite échelle durant tout le XVII ${ }^{e}$ siècle, mais Arkhangelsk fut de loin leur plus importante destination commerciale dans la région de la mer de Barents.

Mots clés: Dvina septentrionale, Arkhangelsk, côte Mourmane, Kola, commerce russe, commerce hollandais, commerce anglais, relations commerciales

Traduit pour la revue Arctic par Nésida Loyer.

\footnotetext{
${ }^{1}$ Arctic Centre, University of Groningen, Oude Kijk in 't Jatstraat 26, Postbus 716, 9700 AS Groningen, The Netherlands

(C) The Arctic Institute of North America
} 


\section{INTRODUCTION}

In the sixteenth century, the Southern Netherlands city of Antwerp was the central entrepôt, the store-house and distribution centre of high-value products for Europe and the world. During their war of independence, the Dutch lost Antwerp to Spain in 1585. After that, they blockaded the port and brought its flourishing sea commerce to a stop. In the decades around 1600, the commercial point of gravity shifted north to the Dutch Republic, which rose to primacy as the dominant shipping and trading nation of Europe and the world. The province of Holland, especially the city of Amsterdam, developed into the main international emporium on a considerably larger scale than Antwerp had been. During the seventeenth century, Dutch entrepreneurs dominated the multilateral, international exchange of commodities. Their business was international commerce, consisting essentially of buying and selling on foreign markets, and importing, processing and re-exporting commodities (Jeannin, 1982; Klein, 1982; Klein and Veluwenkamp, 1993).

England ranked second as a shipping and trading nation (Murphy, 1973). Its commerce was, in essence, based on the bilateral exchange of commodities. In contrast to the Dutch Republic, England re-exported its imports only on a relatively small scale. This meant that the supply which the merchants of England offered their foreign counterparts was largely limited to English products, mainly woollen cloth. And it meant that the demand of the English for foreign commodities was more or less limited to what was needed for their home market. This rendered the English merchants in the international marketplace rather vulnerable to competition from the Dutch. The Dutch, having a much wider range of commodities in supply and demand, outbid them on many markets.

It was, thus, with a very different commercial momentum that entrepreneurs from England and the Dutch Republic in the sixteenth and seventeenth centuries went out to look for new trade routes, new markets and new sources of raw materials. The English were mainly after new markets for their woollen cloth, and a new and safe trade route to the East Indies (Murphy, 1973). The Dutch simply went everywhere they could make a profit in international commerce. One of the new areas the two competing nations opened up was the Northern Sea, subsequently known as the Murman Sea, and finally, much later, as the Barents Sea. The English appear to have arrived there first, in 1553. Thereafter, Western European trade with the Barents Sea littoral and the Russian interior via the North Cape sea route developed rapidly.

Studies devoted to the English and Dutch trade with northern Russia in the sixteenth and seventeenth centuries add up to quite an extensive historiography. Many of them discuss one or more aspects or episodes of the subject in considerable detail, and the general story of this line of international commerce is quite well known. Analytically, nevertheless, the picture is not completely clear. Particularly blurry is the connection between the development of the Northern Dvina delta and the Murman coast—that is, the northern coast of the Kola Peninsula-as commercial destinations. It is obvious that these were the two main places where northern Russia's foreign trade concentrated, but it is less than obvious to what extent they differed or matched functionally. Ahvenainen (1967), for example, hardly discriminates between the two regions, treating them as interchangeable or even undivided destinations. Hart $(1973,1976)$ does discriminate, but his analysis remains very close to the Amsterdam notarial acts he uses as source material, and he omits almost entirely the historical context of his findings. Gromyko (1960) only discusses one, albeit very important, source for the history of the Murman coast trade in transit commodities-the Trade Book, Torgovaja Kniga. A major theme in the historiography is the competition between the English and the Dutch in the Russia trade. Wijnroks (1990) reviews this theme and stresses the role of valuable commodities as a factor in the competitive strength of the Netherlands. In addition, he calls attention to the large degree of continuity in commercial relations between Antwerp and the Baltic port of Narva, and between Amsterdam and northern Russia; merchants of Antwerp switched their Russian traffic from Narva to the northern Russian ports in the 1570s, and moved their operations from Antwerp to Amsterdam around 1590 (Wijnroks, 1990, 1993). Wijnroks discusses the Murman coast as a short-lived alternative to Narva and the Northern Dvina as a trading area for the Russian interior, sprung up from the international trade of the local economy. But further comparison of the commercial functions of the Murman coast and the Northern Dvina is beyond the subject of his study. Schade (1992) covers the commercial relations between Russia and the Netherlands from the fifteenth century to the beginning of the seventeenth century with clear insight. But he does not differentiate between the commercial functions of the two areas either, treating the Murman coast commerce as a stage in the development of the Russian foreign trade, which resulted in the upsurge of the Northern Dvina trade.

In this article, I aim to contribute to the insight into the structure of Western European trade with northern Russia in the sixteenth and seventeenth centuries by explicitly comparing the functions of the Murman coast and the Northern Dvina delta as commercial destinations of the Dutch and the English in the sixteenth and seventeenth centuries (Fig. 1). The central questions concern the economies that the ports of these areas served and the commodities which were traded there. To what extent, in these respects, were the two destinations distinct, and to what extent were they interconnected?

\section{THE TRADITIONAL TRADE OF THE BARENTS SEA LITTORAL}

Before the English and Dutch arrived in the Barents Sea in the 1550s and 1560s, the area had by no means been untouched by human presence. Sami herdsmen, hunters and fishermen had been roaming the plains and valleys of Finnmark and the Kola Peninsula since ancient times (Osherenko and Young, 1989). Since the thirteenth or fourteenth century, Norwegian 


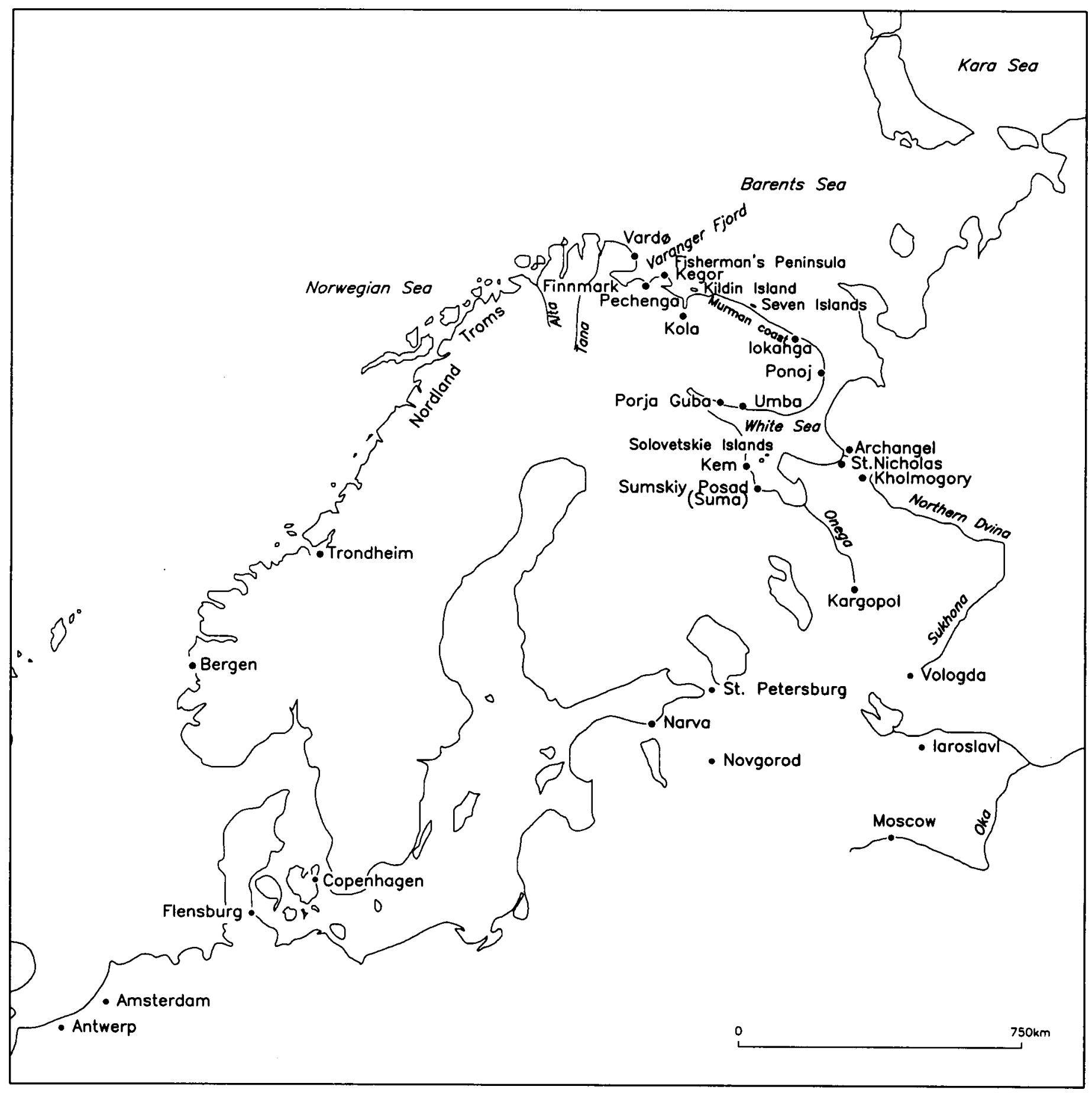

FIG. 1. Arena of the Barents Sea area trade (drawing by H.J. Waterbolk).

fishermen and tradesmen had lived on the Finnmark coast. In the second quarter of the sixteenth century, Russian fishermen from the shores of the White Sea began to travel to the Murman coast to catch cod during the spring season, and from the middle of the sixteenth century, the fishery in this area developed intensively (Ushakov and Dashcinskij, 1983; Nielssen, 1984, 1986; Schrader, 1988).

Until the arrival of the Western Europeans, the commerce of the Barents Sea area had only regional dimensions. The Norwegian fishermen and traders represented the closest the area had come to trade links with Western Europe. Their arrival and settlement on the Finnmark coast seem to have been brought about by the commerce with the Finnmark littoral which had been conducted from the Hanseatic town of Bergen since the twelfth century. The fishermen depended heavily on their trade with Bergen, and they mainly exchanged dried cod for grain products. Within this DanoNorwegian trade system, as Hansen has labelled it, the exchange of fish for ground grain with Bergen, and sometimes with Trondheim, remained the dominating trade of the 


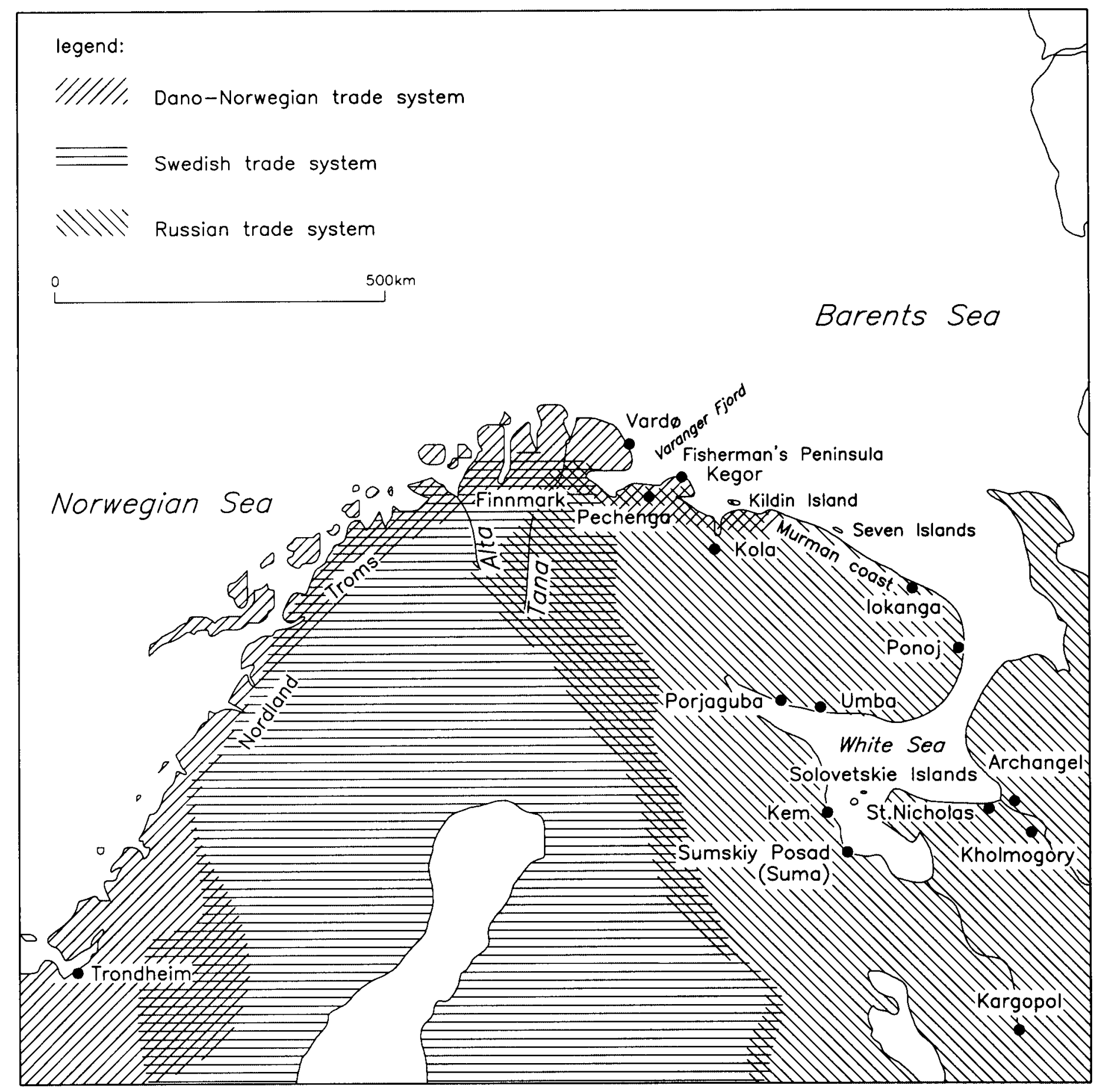

FIG. 2. Trade systems of northern Fenno-Scandinavia A.D. 1550-1600 (Adapted from Hansen, 1984:53; drawing by H.J. Waterbolk).

coastal area extending west of the Varanger Fjord until at least the first half of the eighteenth century (Fig. 2) (Hansen, 1984; Nielssen, 1984, 1986).

The Russian fishermen were attracted to the Murman coast by the dense concentrations of cod and other species that arrived there every spring. They were part of the Russian trade system, which soon after their arrival began to overlap with the Dano-Norwegian system in the Varanger Fjord area as Norwegian merchants established commercial contacts with the Murman coast (Ushakov and Dashcinskij, 1983;
Hansen, 1984; Schrader, 1988). In the first half of the sixteenth century, this trade remained only local in nature. By 1557, Sami, Karelians, Russians and Norwegians were trading at Kegor, on poluostrov Rybachiy, the "Fisherman's Peninsula," situated between Varanger Fjord and the Kola Gulf (Gromyko, 1960; Hakluyt, 1967; Florja, 1973). The monks from the monastery of Pechenga, or Petsamo, located in Munckefjord, between Varanger Fjord and the Fisherman's Peninsula, also became actively involved in the trade. The monastery, consecrated in 1532, had developed a fishing 
and hunting business. In the early $1560 \mathrm{~s}$, its monks used to come to Vard $\varnothing$ to sell fish, train oil and "Wildwahren" (von Salingen, 1914:212; Gromyko, 1960; Ahvenainen, 1967). "Wildwahren" may probably be understood as furs (l'Honoré Naber, 1914). From Vard $\varnothing$, these commodities were shipped to Bergen (von Salingen, 1914). In the second half of the sixteenth century and during the seventeenth century, Norwegian ships called at the ports of Kola, Kholmogory (on the lower Northern Dvina) and Sumskiy Posad (on the Karelian shore of the White Sea). From there, they brought cargoes of Russian grain, tar, cordage and fishery products back to Norway (Schrader, 1988).

The economy of the Sami was linked up with the DanoNorwegian and the Russian trade systems. The Sami, nevertheless, were less dependent on the external trade than the Norwegian - and probably the Russian-fishermen, as they produced more essential products themselves (Nielssen, 1984, 1986). The Sami of Finnmark probably began to sell dried fish in the Norwegian fishing villages in the second half of the Middle Ages. In return, they obtained grain, iron, salt, woollen cloth and other useful products. In the second half of the sixteenth century, the coastal Sami took part in the seasonal commercial fisheries, and by the end of the seventeenth century they were regular customers of the Norwegian tradesmen (Nielssen, 1986). The Sami of the Kola Peninsula carried on seasonal trade in the trading places on the Murman coast, the Fisherman's Peninsula and Kildin Island, just east of the Kola Gulf. The commodities exchanged were similar to those in the Dano-Norwegian trade system; the Sami traded stockfish for foodstuffs and utensils (Hansen, 1984).

The economy of the Sami was also linked to a third commercial system, the Swedish trade system, which extended as far north as Varanger (Hansen, 1984). As early as the sixteenth century, the Sami paid the Swedish crown taxes in the form of furs. The Sami hunters thus contributed to the supply of the royal Stockholm fur market, which met the European demand to a considerable degree up to about the 1570s (Ahvenainen, 1967).

\section{ENGLISH AND DUTCH TRADE WITH THE NORTHERN DVINA DELTA}

\section{English Beginning}

The opening of the West European trade with Russia via the Northern Dvina delta occurred as a side effect of the English search for a northeast passage to Asia. This search was induced by the British desire to share in the lucrative trade in Asian commodities, especially spices, which the Portuguese dominated in the sixteenth century. In the middle of that century, England did not have the military power to undermine the Portuguese position, but in circles of geographers and navigators the idea was growing that a sea passage to Cathay could be found by way of the northeast, over the top of Europe. An important stimulus for actually sending an expedition was the stagnation and decline in demand for
English woollen cloth on the European market after 1550. Traditionally, woollen cloth was by far the most important export of England. Now that this trade had dried up, alternative markets and trade possibilities had to be found (Murphy, 1973).

The first English expedition to search for a northeast passage occurred in 1553 and was led by Hugh Willoughby (Murphy, 1973). North of Lapland the three participating ships lost each other in storm and fog. Richard Chancellor, the captain of one of the vessels, drifted with his ship into the White Sea and landed at the mouth of the Northern Dvina. From there, Chancellor travelled to Moscow where he was received by Tsar Ivan the Terrible. Both the seaman and the tsar realised the importance of the shipping route to Russia around North Cape and via the White Sea. During summer the Northern Dvina was entirely navigable and an excellent shipping link with the interior and Moscow. Soon, the new route to Russia was being used for commercial transport between Western Europe and central Russia (Lubimenko, 1933; Murphy, 1973; Bushkovitch, 1980).

The route, indeed, was new, although trade with Russia was not. For a long time, Russia had had regular commercial relations with the West via the Baltic. The Hanseatic League had had an office in Novgorod since the early thirteenth century. Novgorod exported, among other things, furs from the Northern Dvina basin. As early as the beginning of the fifteenth century, Novgorod had contacts with the Netherlands, whence woollen cloth, linen, subtropical fruit, salt, beer, wine, herring and metal-ware were brought. Many of these commodities were sold to the Russian market. The old routes to Western Europe crossed the territories of the German Order, Lithuania, Poland and Sweden, which separated Russia from the Baltic. This meant that the tsar was dependent on other powers for his contacts with Western Europe (Bezemer, 1988; Wijnroks, 1990; Schade, 1992). In the sixteenth century, the importance of these contacts grew. Western Europe had a large technical and economic lead on Russia, and the tsar wished to provide himself not only with precious metals and luxuries, but with arms and technical knowledge for waging war against the Tatars and PolandLithuania. But precisely because of the Russian menace, Sweden and Poland-Lithuania frustrated the tsar's trade with Western Europe where they judged it dangerous. So, the tsar had good reason to stimulate the use of the newly discovered White Sea route. In 1555, two years after Chancellor's voyage, English merchants founded the Muscovy Company, with the aim of carrying on trade with Russia (Willan, 1948; Schade, 1992). From the English crown, the Muscovy Company obtained a monopoly of the commerce with Russia; the tsar granted them freedom of duty and movement within Russia-but not the monopoly of the northern route (Hart, 1969; Murphy, 1973).

Woollen cloth was apparently the main commodity the Muscovy Company imported into Russia. Metals (tin, copper and lead) were another important category of commodities the Company sold to the Russians (Lubimenko, 1933; Willan, 1948; Attman, 1973; Wijnroks, 1990). In addition, the English 
brought to Russia cotton fabrics, arms and ammunition, paper, wine, subtropical fruit, salt, medicines, East Indian commodities and, sometimes, precious metals (Lubimenko, 1933; Attman, 1973; Wijnroks, 1990). From Russia, they exported train oil, furs, wax, wood for masts, flax, hemp, cable-rope, tallow and skins (Lubimenko, 1933; Attman, 1973). This trade involved mainly an exchange of commodities with the Russian interior. To a small degree, the products exported, such as train oil, and part of the furs and skins, were produced in the Barents Sea area itself.

Until the end of the 1570s, the Muscovy Company did not experience any competition in the Northern Dvina trade. Nevertheless, the English traders did not have an easy start. The first successful return voyage, without damage to the ships and their cargoes, did not apparently occur until 1560. Before 1567, the Company sent at most four ships a year, and after that, until 1581, a maximum of ten ships annually to St. Nicholas, its anchorage in the delta of the Northern Dvina. The Muscovy Company never became a great success (Willan, 1948; Wijnroks, 1990; Schade, 1992).

\section{Dutch Sequel}

The lack of British success may be partly explained by the fact that Russia conquered the Baltic port of Narva from the German Order in 1559. Subsequently, Russia carried on its foreign trade, in which both the English and the Dutch had a large share, mainly via Narva. As long as this route was open, trade via the Northern Dvina was a matter of relative indifference to the Russian government. The definitive breakthrough of the Northern Dvina mouth as an area of international trade was only triggered as Sweden blockaded Narva and caused the port's sea traffic and trade to decline sharply in the $1570 \mathrm{~s}$ (Gromyko, 1960; Wijnroks, 1990; Schade, 1992). Eventually, in 1581, Russia lost Narva to Sweden; but by then, the tsar had already set out to promote the northern traffic, and at least part of Russia's foreign trade and of the Dutch commercial connections shifted from Narva to the North, while the Muscovy Company sent probably more ships to St. Nicholas after 1581 than before (Willan, 1948; Hart, 1969; Wijnroks, 1990). Dutch entrepreneurs sent ships to the delta of the Northern Dvina for the first time in 1578 (Muller, 1874; l'Honoré Naber, 1914; Florja, 1973). Among them was the Antwerp merchant Jan van de Walle, who soon acquired his own pier on the river and partial freedom from tolls, and became a supplier of valuable fabrics to the Russian court (Muller, 1874; Kordt, 1902; Kellenbenz, 1973; Wijnroks, 1990, 1993). The new importance of the Northern Dvina trade made the tsar found a new seaport in 1584, on the spot where the Dutch had begun to moor their ships, near the monastery of the Archangel Michael situated on the right bank of the Northern Dvina where the river opens into a delta. Initially known as Novye Kholmogory, the new port was soon renamed Archangel, after the monastery. Archangel was built as, and quickly became, the sole port of trade for the Russian interior (Jansma, 1946; Il'ina and Grachov, 1987; Schade, 1992).
The Dutch exported much the same commodities as the English from the Northern Dvina: train oil, furs, wax, potash, flax, hemp, skins, tallow and caviar (Attman, 1973). From the beginning of the 1580 s, they started real competition with the English. In 1582, about ten English and ten Dutch trading vessels called at the Northern Dvina delta. By 1600, ten to twenty Dutch ships went to Archangel every year, whereas the English sent only about half as many. And by the second decade of the seventeenth century, the Dutch had squeezed the English almost completely out of the Russian market. By that time, probably, the English sent three or four ships to Archangel annually, while the Dutch sent three or four dozen (Ahvenainen, 1967; Hart, 1969; Kellenbenz, 1973; Wijnroks, 1990, 1993).

The most important underlying cause of all this was the divergence of the economic developments of England and the Dutch Republic. As mentioned earlier, the English supply and demand on foreign markets was more or less limited to that of the English home market. The Dutch, on the other hand, bought and sold for wider markets. Consequently, there was virtually no limit to the nature and the volume of the commodities they supplied and demanded. This implied that, on many markets, the Dutch could outbid the Englishwhich is exactly what they did in Russia. They imported the valuable goods that the Russian market demanded, but the English could not supply (Wijnroks, 1990; Schade, 1992). An important competitive edge of the Dutch over the English was their ability to meet the Russian demand for precious metals, especially silver. The Russian balance of trade was strongly active. Foreign merchants had to pay the deficit in ready money. The financially strong Amsterdam staple market was able to absorb the negative balance of trade with Russia, and the Dutch exported rixdollars and ducats without difficulty. The Dutch paid the Russian tolls in silver money, and also paid for the Russian commodities, at least partly, in ready money. Moreover, they were able to give credit. The English did not have to pay tolls and carried on barter trade. They were not able to supply precious metals in sufficient quantity. England needed all available bullion for the East India Company; English merchants were not allowed to export their own currency in excess of that. It is clear that the financial weakness of the English was detrimental to the competitive power of the Muscovy Company (Hart, 1969; Bruijn, 1977; Schade, 1992).

Archangel remained the sole seaport for interior Russia for more than a century. Only from 1721, after the Great Northern War, did St. Petersburg, too, play an important role (Busching, 1790; Knoppers, 1976; Schade, 1992). Throughout the seventeenth century, Dutch commercial contacts with Russia remained concentrated in Archangel. On average, at least 35 Dutch vessels called at the northerly port annually, and many more when war interfered with the connections with the Baltic (Hart, 1976; Bruijn, 1979; Klompmaker, 1980). Besides silver coins and gold coins, the Russian imports via Archangel consisted mainly of military stores and luxury goods for the tsar and the rich nobility. These included pearls, precious stones, luxury textiles (woollen cloth, silk, 
velvet, linen, damask, gold and silver brocade, gold and silver lace, gold and silver thread and braid), arms, copper, brass, pewter, lead, iron, spices, groceries, wine, sugar, paper, dyes (indigo, brazil) and building materials (Attman 1973; Klompmaker, 1980). Russia exported via Archangel mainly the produce of its forests, farms, and fisheries. The exports included train oil, masts, woad ashes, potash, tar, wax, furs, skins, bristles, Russia leather, tallow, hemp, flax, grain and caviar. In addition, Russia re-exported silk from Persia (Attman, 1973; de Buck, 1988). The Archangel trade involved mainly the exchange of commodities with interior Russia. Few of the exports were produced in the Barents Sea area itself-probably a portion of the furs, and certainly the train oil and the sealskins. These, however, accounted for only a fraction of the value of the total exports (Attman, 1973).

\section{DUTCH TRADE WITH THE MURMAN COAST}

\section{The First Commercial Contacts}

Probably in the early 1560 s, ten years after the first arrival of the English in the Northern Dvina delta in 1553, the Dutch opened another sphere of northern commerce by establishing trade connections with the local economy of the Murman area and its northern Russian hinterland. Since the Middle Ages, they had visited the coasts of Norway to buy fish and whale oil, and they had visited northern Norway even before 1553 . Their presence in northern Norway was probably connected with the Hanseatic trade of Bergen (Ahvenainen, 1967; Schade, 1992).

According to a widespread historiographical tradition, Dutchmen had participated in the trade on the Fisherman's Peninsula on the Murman coast as early as 1557 and even before that. This tradition is based on the contemporary account of Stephen Burrough (Hakluyt 1967; Hansen, 1984; Wijnroks, 1990; Schade, 1992). As early as 1902, Kordt expressed doubt about the correctness of this interpretation of Burrough's account. He argued that the first direct commercial contact of the Dutch with the Munckefjord-Pechenga area was made by the Dutchman Philips Winterkoning in the first half of the 1560s, and that this contact marked the beginning of the Dutch trade with the Murman coast (Kordt, 1902). The issue has not yet been settled. Kordt's doubt has been neglected, however, and his arguments have not yet been convincingly contested (see Schade, 1992).

Winterkoning's story remains a good one. His venture was recorded by his contemporary Simon von Salingen, another pioneer of the northern commerce. In the early 1560s, Winterkoning worked for the Danish governor of Vard $\varnothing$. At some stage, he left the governor's service and went to Antwerp. In 1564, he sailed from Antwerp back to Vardø on a ship of the company that he had founded with two Antwerp merchants. However, by then Vardø had a new governor, who accused Winterkoning of violating the trade privileges of Bergen and Trondheim and denied him and his men further access to Vardø. Winterkoning was forced to sail away, but before he did so, the monks of Pechenga-who, as noted above, carried on trade with Vardø in those years-took advantage of the situation and suggested that he come to the Munckefjord the next year to buy fish, salmon, train oil and "Wildtwaren" [sic].

The following year, 1565, Winterkoning sailed to Munckefjord, loaded his ship with fish, salmon, train oil and "other commodities," and sent it back to his associates. He himself hired a Russian ship to sail to the White Sea, to St. Nicholas, and to travel from there on to Moscow. The ship was loaded with Winterkoning's remaining commodities, among which were wine and woollen cloth. On their way, however, in an inlet of the Murman coast, Winterkoning and his men were robbed and killed by Russian sailors (Kordt, 1902; l'Honoré Naber, 1914; von Salingen, 1914:212).

Following Winterkoning's death, a few Dutch ships sailed annually to the Pechenga monastery to trade with the monks, and also with Russian traders who were attracted from distant places like Kholmogory and Kargopol. The monastery prospered. In 1565, it had about 20 monks and 30 lay hands, and by 1572 , these figures had risen to 50 and 200 respectively. By that time the monks controlled the salmon fishery in the inlets between the Fisherman's Peninsula and the Varanger Fjord (von Salingen, 1914). In about 1590, the monastery was burnt down by the Finns, but Pechenga remained a destination for traders at least throughout the 1590s (Ahvenainen, 1967).

Before his fatal and abortive journey to Moscow, Winterkoning had written to his associates asking them to send additional commodities. They did, indeed, send two more ships, which arrived in the Munckefjord in the autumn of 1565. The monks sent one ship back to Antwerp with news of Winterkoning's fate, and the other to the hamlet of Kola to winter. At that time, Kola had only three houses. The next year, 1566, Winterkoning's company sent its bookkeeper Simon von Salingen with two more ships, loaded with cloth, pepper, tinware and other commodities, to Munckefjord to try and recover Winterkoning's lost goods and to carry on trade. Von Salingen loaded his two ships and the vessel that had wintered at Kola with fish, train oil, salmon and other commodities at Munckefjord and on the Fisherman's Peninsula. No cargo was available at Kola at that stage, but in the years that followed, Dutch trading vessels began to arrive at Kola annually, and the hamlet began to grow as a trading place, taking part-along with Pechenga — in the new, developing, foreign commerce of the Murman coast (von Salingen, 1914; Ahvenainen, 1967).

\section{The Kola Boom in the 1570s}

Throughout the 1560s, the foreign trade of the Murman coast was limited mainly to the exchange of the area's products for commodities used locally. The Dutch bought local products, namely dried and salted cod, train oil, blubber and skins of marine mammals, oil of cod and shark, salmon, furs, and mica, and perhaps, to some extent, products from the northern Russian hinterland, such as wax, flax and leather. 
They brought commodities for local use, like salt for the export fisheries, and probably wine, woollen cloth, pepper and tinware (von Salingen, 1914; Gromyko, 1960; Ahvenainen, 1967). All this changed in the 1570s, as the Swedish blockade of Narva and the Russian policy to promote trade via the North boosted not only the trade of the Northern Dvina but also that of the Murman coast. The Dutch continued their traditional business with the area, but the range of the commodities traded expanded significantly. By 1575 , the exports via the Murman coast included a wide range of produce from the Russian interior, such as tallow, skins, flax, hemp, grain, furs, wax, tar, pitch and ash (Gromyko, 1960; Hart, 1969; Wijnroks, 1990). Its imports now included dried fruit, spices, sugar, chemicals, medicines, metals, metal wares, and most likely also woollen cloth, wine and precious metals. In the course of the 1570s, Kola became the most important port of the Murman coast (von Salingen, 1914; Gromyko, 1960; Attman, 1973). In 1574, it had 44 homesteads (Ushakov and Dashcinskij, 1983). It remained an international commercial port for the economy of the Kola Peninsula, but, in addition, it developed into a thriving centre of commercial exchange between interior Russia and Western Europe, where visiting Western European merchants and Russian traders met and traded (Gromyko, 1960; Hansen, 1984; Wijnroks, 1990). In 1582, the first voevoda, or governor, of Kola was appointed by the tsar. He set up a trade centre with storage accommodation for the foreign commerce, founded a weigh-house, and started levying toll (von Salingen, 1914; Ahvenainen, 1967; Ushakov and Dashcinskij, 1983).

The commerce at Kola seems to have been conducted during an annual fair, held at Petermas on 29 June. Among the participating Russian traders were inhabitants of Kola itself as well as merchants from the towns of the lower Northern Dvina, such as Kholmogory, and from White Sea towns, such as Suma and Kem (Hansen, 1984). Most foreign merchants visting Kola came from the Netherlands (Ahvenainen, 1967). Indeed, the commercial relations with the Dutch were paramount in the foreign trade of the Murman coast (Gromyko, 1960). The Dutch were so active that, in 1575, the English Muscovy Company was warned it would be left out in the cold by the Dutch and Flemings unless it soon began to take the trade with Lapland seriously (Hacquebord, 1988). Some English merchants who, in 1578, prepared a journey to Kola declared in a memorandum that they planned to drive the Dutch out of the Kola trade within two or three years. In practice, however, the role of the English seems to have been quite modest. Indeed, there are no records of English vessels in Kola at all (Ahvenainen, 1967).

\section{The Narrowing of the Murman Coast Trade Between 1585 and 1620}

The Kola commercial boom was short-lived. In the second half of the 1580s, the tsar changed his policy and decided to direct all foreign trade with interior Russia via Archangel. After 1585, by edict of the tsar, the Kola export was confined to locally produced commodities (Gromyko, 1960). Kola lost its share of interior-Russian trade and remained only a centre of regional production and export.

The composition of the Kola export of local products narrowed again about 1600 and shortly after. In the 1560s, there was mention of fish, salmon, train oil and "Wildwahren" as exports of the Murman coast. Similarly, in about 1575, dried and salted cod, salmon, train oil, blubber and fish oil, and furs were listed, and, in addition, mica. In the seventeenth century, cod and salmon remained as major exports, but furs had virtually disappeared, and train-oil and blubber seem to have become of secondary importance. Mica can hardly be imagined to have ever been a quantitatively important export (Ahvenainen, 1967; Hart, 1976). A decline of train oil export can be explained by the fact that the Dutch started whaling and producing whale oil themselves from about 1615 , hunting in the waters off the west coast of Spitsbergen (Hacquebord, 1984, 1988). Furs probably disappeared as a Murman coast export about 1600, as a result of over-hunting of the animals caused by the rise in the demand for furs generated by the foreign merchants (Ahvenainen, 1967). The depletion of furred animals deprived the Sami of an important source of barter. To be able to continue their trade with the foreigners, the Sami had increasingly to rely on the constant foreign demand for fish. Thus, the Sami chose-or were forced by circumstances - to lay more emphasis on fishing than before, and, to some extent, to move from the interior to the coast (Ahvenainen, 1967). The depletion of the furred animals, of course, was a relative phenomenon. The animals by no means became extinct. In 1653, the Danish party accompanying the French traveler de la Martinière acquired skins of wolf, fox and squirrel on the Varanger coast, and skins of lynx, fox and ermine at Kola (Kosheckin, 1991).

The Dutch continued to visit Kola to buy cod. The cod fishery was a seasonal activity, dependent on the arrival of the fish. In spring and early summer, the number of inhabitants of Kola exploded. Hundreds, even thousands of Pomors, Russian dwellers of the White Sea coasts, came to Kola and used it as a base from which they shuttled in their small, open boats to and from the fishing grounds. The permanent inhabitants of the hamlet, too, mainly lived from the fisheries. They were fishermen themselves and, in addition, they provided board and lodging for the seasonal workers. They also supplied them with equipment, such as fishing boats, which they built themselves (Ushakov and Dashcinskij, 1983). Russian and foreign merchants came over to buy cod during the summer. The Russians came from the Northern Dvina, from Kargopol up the river Onega, and from other towns. By this time, Kola had a trade centre for Russian merchants, one for foreigners, and a separate centre for the Dutch (Ushakov and Dashcinskij, 1983). The non-Dutch foreigners who came to Kola to buy fish were probably predominantly Norwegians.

The purchase of salmon was the other main economic activity of the Dutch on the Murman coast in the seventeenth century. It was an intensive business. For about three months every year, Dutchmen sailed along the Murman coast gathering the precious fish, which were caught in the rivers by the local population. For that purpose, they travelled in boats far 
up the rivers. The Dutch crews themselves usually cleaned, salted and barreled the fish. Often, specially for the barreling, coopers came along from the Netherlands. They were put ashore at various places to make barrels and to fill them with salmon. The Dutch called at, among other places, Kegor (on Fisherman's Peninsula), Kola, Kildin, Sem-Ostrovov (Seven Islands), Iokanga and Ponoj; and they even sailed beyond the Murman coast to Umba and Porja Guba on the south coast of the Kola Peninsula in the Kandalakshskij Bay of the White Sea (Ahvenainen, 1967; Hart, 1976; Hacquebord, 1988). The Lapland salmon seems to have been "goed en lieflijk van geur en roodachtig van kleur" ("of a good and lovely smell and of a reddish colour") (Hart, 1976:280).

Dutch vessels kept coming in small numbers to the Murman coast "to fish," as this trade was called, all through the seventeenth century (Hart, 1976). Through archival research, the Dutch historian P. de Buck has shown that the number of Dutch ships sailing to the Murman coast usually amounted to one to four in the period from 1590 to 1670 , and to only one, and in many years even none, in the period from 1670 to 1725. Up to 1670 , most of these ships had both the Murman coast and Archangel as their destinations (P. de Buck, pers. comm. 1992). Some of them put into Kola or other harbours on the Murman coast for a few days on their way to or from Archangel. Others were freighted to sail to the Murman coast but also had to call briefly at Archangel to land part of their cargo. Moreover, the salmon loaded in Archangel often had been brought in from Lapland (Ahvenainen, 1967; Hart, 1976).

\section{CONCLUSION}

The historiography of English and Dutch trade with the Barents Sea area in the sixteenth and seventeenth centuries tends to link the Murman coast trade and the Northern Dvina trade, and to hardly discriminate between them. Closer observation, however, leads to the conclusion that the Murman coast trade and the Northern Dvina trade largely coincided with two clearly distinct branches of commerce-respectively, the trade with the coastal economy of northern Russia, and the transit trade with the Russian interior. The trade with the coastal economy involved basically the exchange of locally produced exports like cod, salmon, furs and train oil for locally used imports like cloth, tinware, salt, pepper, and wine. The transit trade with interior Russia involved the exchange of the north and central Russian forestry and agriculture products for gold and silver money and a wide range of military stores and luxury goods. It is true that many of the Dutch ships sailing the Murman coast also called at Archangel in the course of a single journey. And it is true that the trade with the coastal economy was conducted not only on the Murman coast, but also on the Northern Dvina. But it is equally true that the Murman coast trade was essentially limited to the trade of the littoral, whereas the transit trade with interior Russia was exclusively a Northern Dvina business. Only from the early 1570 s to about 1585 was Kola used as an alternative to the Northern Dvina mouth as a port for the transit trade with interior Russia, and then only by the Dutch. To a large extent, the Murman coast commerce may be identified with the trade with the coastal economy, while the Northern Dvina commerce may be identified with the transit trade with the Russian interior.

\section{REFERENCES}

AHVENAINEN, J. 1967. Some contributions to the question of Dutch traders in Lapland and Russia at the end of the sixteenth century. Acta Lapponica Fenniae 6:1-53.

ATTMAN, A. 1973. The Russian and Polish markets in international trade. Gothenburg: The Institute of Economic History, Gothenburg University.

BEZEMER, J.W. 1988. Een geschiedenis van Rusland: Van Rurik tot Brezjnev. Amsterdam: G.A. van Oorschot.

BRUIJN, J.R. 1977. De vaart in Europa. In: Akveld, L.M., Hart, S., and Hoboken, W.J. van, eds. Maritieme geschiedenis der Nederlanden. Vol. 2. Bussum: De Boer Maritiem. 200-241. 1979. Scheepvaart in de Noordelijke Nederlanden 1650 1800. In: Algemene Geschiedenis der Nederlanden. Vol. 8. Haarlem: Fibula - Van Dishoeck. 209-238.

BUCK, P. de. 1988. De Russische uitvoer uit Archangel naar Amsterdam in het begin van de achttiende eeuw (1703 en 1709). Economisch- en Sociaal-historisch Jaarboek 51:126-193.

BUSCHING, A.F. 1790. Nieuwe en volledige geographie of aardryksbeschryving. Vol. I. Part 2. Rusland, Pruissen, Polen, Hongaryen en Europisch Turkyen, naar den vierden druk uit het Hoogduits vertaald en met des schryvers afzonderlyk schriftlyk medegedeelde vermeerderingen verrykt. Amsterdam: H. Gartman, W. Vermandel en J.W. Smit.

BUSHKOVITCH, P. 1980. The merchants of Moscow, 15801650. Cambridge: Cambridge University Press.

FLORJA, B.N. 1973. Torgovlja Rossii so stranami Zapadnoj Evropy v Archangel'ske (konec XVI - nacalo XVII v.). Srednie Veka 36:129-151.

GROMYKO, M.M. 1960. Russko-niderlandskaja torgovlja na Murmanskom beregu v XVI v. Srednie Veka 17:225-255.

HACQUEBORD, L. 1984. Smeerenburg. Het verblijf van Nederlandse walvisvaarders op de westkust van Spitsbergen in de 17de eeuw. Ph.D. thesis, University of Amsterdam.

1988. West-Europese walvisvaart in de kustwateren van Finnmarken (Noord-Noorwegen) in de 16de en 17de eeuw. Tijdschrift voor Zeegeschiedenis 7:4-13.

HAKLUYT, R. 1967. Voyages. Vol. 1. With an introduction by J. Masefield. Everyman's Library 264. London: Dent.

HANSEN, L.I. 1984. Trade and markets in northern FennoScandinavia A.D. 1550-1750. Acta Borealia 1(2):47-79.

HART, S. 1969. De handelsbetrekkingen van Amsterdam met Archangel en Lapland (Kola) in de 17e eeuw. Nederlands Archievenblad 73:66-80.

- 1973. Amsterdam shipping and trade to Northern Russia in the seventeenth century. Mededelingen van de Nederlandse Vereniging voor Zeegeschiedenis 26:5-30, 105-116.

. 1976. Amsterdamse scheepvaart en handel op NoordRusland in de zeventiende eeuw. In: Hart, S. Geschrift en Getal. 
Een keuze uit de demografisch-, economisch en sociaalhistorische studiën op grond van Amsterdamse en Zaanse archivalia, 1600-1800. Hollandse Studien 9. Dordrecht: Historische Vereniging Holland. 267-314.

HONORÉ NABER, S.P. l', ed. 1914. Reizen van Jan Huyghen van Linschoten naar het Noorden (1594-1595): Werken uitgegeven door de Linschoten-Vereeniging VIII.'s-Gravenhage: Martinus Nijhoff.

IL'INA, L.L., and GRACHOV, A.N. 1987. Reki severa. Leningrad: Gidrometeoizdat.

JANSMA, T.S. 1946. Olivier Brunel te Dordrecht: de Noordoostelijke doorvaart en het Westeuropeesch-Russisch contact in de zestiende eeuw. Tijdschrift voor Geschiedenis 59:337-362.

JEANNIN, P. 1982. Les interdépendences économiques dans le champ d'action européen des Hollandais (XVIe-XVIIIe siècle). In: Aymard, M., ed. Dutch capitalism and world capitalism. Cambridge: Cambridge University Press. 147-170.

KELLENBENZ, H. 1973. The economic significance of the Archangel route (from the late 16th to the late 18 th century). The Journal of European Economic History 2(3):541 - 581.

KLEIN, P.W. 1982. Dutch capitalism and the European worldeconomy. In: Aymard, M., ed. Dutch capitalism and world capitalism. Cambridge: Cambridge University Press. 75-92.

KLEIN, P.W., and VELUWENKAMP, J.W. 1993. The role of the entrepreneur in the economic expansion of the Dutch Republic. Economic and Social History in the Netherlands 4:27-53.

KLOMPMAKER, H. 1980. Handel, geld- en bankwezen in de Noordelijke Nederlanden 1580-1650. In: Algemene Geschiedenis der Nederlanden. Vol. 7. Haarlem: Fibula - Van Dishoeck. $98-$ 127.

KNOPPERS, J.V.Th. 1976. Dutch trade with Russia from the time of Peter I to Alexander I. A quantitative study in eighteenth century shipping. 3 vols. Montreal: Interuniversity Centre for European Studies.

KORDT, V.A. 1902. Ocerk snosenij Moskovskago gosudarstva s Respublikoju Soedinennych Niderlandov do 1631 g. In: Sbornik Imperatorskago Russkago Istoriceskago Obshcestva. Vol. 116. St.Petersburg.

KOSHECKIN, B.N. 1991. Imena na skale. Archangelsk: SeveroZapadnoe Knizhnoe Izdatel'stvo.

LUBIMENKO, I. 1933. Les relations commerciales et politiques de l'Angleterre avec la Russie avant Pierre le Grand. Paris: Librairie Ancienne Honoré Champion.

MULLER FZ., S., 1874. Geschiedenis der Noordsche Compagnie. Utrecht: Gebroeders van der Post.
MURPHY, B. 1973. A history of the British economy 1086-1970. London: Longman.

NIELSSEN, A.R. 1984. Animal husbandry among the Norwegian population in Finnmark c.1685-1705. Acta Borealia 1(2):81 112.

- 1986. Economic adaptation among the Coast Sami population in Finnmark c.1700. Acta Borealia 3(1):21-41.

OSHERENKO, G., and YOUNG, O.R. 1989. The age of the Arctic: Hot conflicts and cold realities. Cambridge: Cambridge University Press.

SALINGEN, S. von. 1914. Simon von Salingens Bericht, de Ao. 1591. Wegen der Landschafft Lappia, wie die Anno 1562. 63. 64. und 65. ausz Niederlant ist besiegelt worden, und wie Simon von Salingen zu seiner Ankunft die Land gebawet, und in ihrer Gestalt gefunden, und folgendtsz mehr Segellatz, und bawunge, durch die Commercien erfolgt ist. In: Honoré Naber, S.P. 1', Reizen van Jan Huyghen van Linschoten naar het Noorden (1594-1595). Werken uitgegeven door de LinschotenVereeniging. Vol. VIII. 's-Gravenhage: Nijhoff. 211-222.

SCHADE, H. 1992. Die Niederlande und Russland. Handel und Aufnahme diplomatischer Kontakte zu Anfang des 17. Jahrhunderts. European University Studies, Series III, History and Allied Studies, Vol. 409. Frankfurt am Main: Peter Lang.

SCHRADER, T.A. 1988. Pomor trade with Norway. Acta Borealia 5(1/2):111-118.

USHAKOV, I.F., and DASHCINSKIJ, S.N. 1983. Kola. Murmansk: Murmanskoe Knizhnoe Izdatel'stvo.

WIJNROKS, E.H. 1990. Anglo-Dutch rivalry in Russian trade in the latter half of the 16th century: A historiographical essay. In: Lemmink, J.Ph.S., and van Koningsbrugge, J.S.A.M., eds. Baltic affairs, relations between the Netherlands and NorthEastern Europe, 1500-1800, essays. Baltic studies. Vol. I. Nijmegen: Institute for Northern and Eastern European Studies. $413-432$.

. 1993. Jan van de Walle and the Dutch silk-trade with Russia, 1578-1635. In: Braat, J., Huussen, A.H., Jr., Naarden, B., and Willemsen, C.A.L.M., eds. Russians and Dutchmen. Proceedings of the Conference on the relations between Russia and the Netherlands from the 16th to the 20th century held at the Rijksmuseum Amsterdam, June 1989. Baltic Studies. Vol. II. Groningen: Institute for Northern and Eastern European Studies. 41-58.

WILLAN, T.S. 1948. Trade between England and Russia in the second half of the sixteenth century. The English Historical Review 63:307-321. 